\title{
The Effects of Different Types of Feedback in the EFL Writing Class: A Study of Efficiency, Affective and Cognitive Aspects, and Thai Cultural Dimensions
}

\author{
Raveewan Wanchid
}

Assistant professor, King Mongkut's University of Technology North Bangkok, Thailand

\begin{abstract}
ARTICLE INFO
Keywords:

EFL students

Online peer feedback

Paper-pencil peer feedback

Self-correction

Writing instruction

ABSTRACT

The purposes of this research were to 1) compare the effects of selfcorrection, paper-pencil peer feedback, and online peer feedback on the students' writing achievement; 2) compare the effects of the students' levels of general English proficiency (high, moderate and low) on writing achievement; 3 ) investigate the interaction effect between the types of feedback and levels of general English proficiency on the students' writing achievement; and 4) survey the students' attitudes toward the use of feedback activity they experienced in terms of its efficiency, affective and cognitive aspects, and Thai cultural dimensions. The study was conducted with 72 engineering students having different levels of general English proficiency. They were randomly selected and assigned into three groups. Two-way Analysis of Variance (ANOVA), descriptive statistics, and content analysis were used to analyze the data. The questionnaire and interview were used to gain more indepth data. The results revealed that the different types of feedback and levels of English proficiency had a significantly different effect on the students' writing achievement, and the interaction effect was also found.
\end{abstract}

\section{Introduction}

Feedback has a vital role to play in a writing class since it is considered as critical in improving and consolidating learning (Hyland, 2003). For teachers, it provides crucial information of a student's progress as well as for evaluating their teaching during the course. Providing feedback in the EFL writing class is believed to be a teacher's major responsibility due to the higher-context cultures in which authority is primarily in the teachers' hands and students feel that it is inappropriate to question teachers. In other words, teachers are viewed as the givers of knowledge while students are considered inexperienced and not in a position to share or express ideas (Baker, 2013). However, the controversial issue is whether teacher correction is really useful and helps students learn more effectively than other feedback strategies. Since the paradigm shift of language learning to the learner-centered approach, students have been encouraged to be independent learners that can learn autonomously, show their own voices, and critically express their opinions. As a result, peer feedback strategies have been applied in the EFL writing class.

Self-correction is a strategy according to which students read, analyze, correct, and evaluate their own writing by using guided questions or checklists, both form-focused and meaning focused. There are several advantages to self-correction: it helps increase students' independence from the teacher, students remember better from their own mistakes and are

* Corresponding Author E-Mail Address: rwanchid@hotmail.com 
aware of their own strengths and weaknesses in writing, and it saves time in large classes (Yang, 2010). Ancker (2000) found that self-correction helps to focus student attention on errors and to reduce reliance on the teacher, thereby encouraging student autonomy. However, students may find it very demotivating about finding the mistakes due to no readers.

Peer feedback is a writing activity in which writers work in groups collaboratively and provide information on each other's writing, either in a written, oral, or computer-mediated mode (Liu \&Hansen, 2002). Through feedback, the writer learns where he or she has misled or confused the readers by not supplying sufficient information or with illogical organization, lack of the development of ideas, or inappropriate words choice or tense. This supports Vygotsky's idea of the zone of proximal development, where skills are extended through the guidance and response of others. It is believed that feedback from more advanced peers can provide scaffolding and can reduce problems associated with peer feedback, such as the lack of credibility of peer evaluation and reluctance to use feedback from peers. However, the effectiveness of using peer feedback in the EFL writing class is still a controversial issue due to students' English proficiency and cultural impacts, such as avoiding truthful comments to preserve a harmonious relationship among group members and being reticent in the group discussions.

Interestingly enough, the way to provide feedback has also moved from the traditional paperpencil or face-to-face mode to the online mode with the great influence of computer technology. Many social networking sites such as Facebook, Google Docs, and Weblog have become popular and are utilized in the writing class. Although many writing instructors use social networking sites in their classes, their usefulness and constraints in terms of its efficiency, affective and cognitive aspects, and cultural dimensions, especially in the Thai context, have not yet been clearly revealed. In this study, Facebook, a free social networking site program, will be applied due to its beneficial functions for students and teachers to submit and check their homework, provide and receive comments on students' assignments, and interact with teachers and classmates, for example.

As a result, in order to solve the problems mentioned above, three alternative strategies to providing feedback on the students' writing assignments are proposed: self-correction, paperpencil peer feedback, and online peer feedback. It is hypothesized that this worthy activity will possibly help the teachers and students overcome the constraints apparent in the teaching and learning context in the workplace and possibly equip students with the mindset of independent learning in the writing class. It is certainly worthwhile to investigate which type of feedback is the most effective strategy to be used in the EFL writing class.

\subsection{Research Objectives}

1. To compare the effects of self-correction, paper-pencil peer feedback, and online peer Feedback on the students' writing achievement

2. To compare the effects of the students' levels of general English proficiency (high, Moderate and low) on writing achievement

3. To investigate the interaction effect between the types of feedback and levels of general English proficiency on the students' writing achievement

4. To survey the students' perceptions toward the use of self-correction, paper-pencil peer feedback, and online peer feedback in terms of efficiency, affective and cognitive aspects, and Thai cultural dimensions

\section{The Experimental Process and Data Collection}

In order to ensure that the students could provide effective peer feedback, they were trained at the beginning of the course. The writing achievement test and close-ended questionnaire were used for the quantitative data collection. Two way Analysis of Variance (ANOVA) and 
descriptive statistics were used to analyze and explain the data. The qualitative data were gathered from the interview. The following table describes the experimental process of the study.

Table 1.

The experimental process and data collection

\begin{tabular}{clc}
\hline Phases & \multicolumn{1}{c}{ Activities } & Weeks (1-15) \\
\hline I & The students took the pre-test. & 1 \\
& The students were divided into three groups: self-correction, & $2-3$ \\
- & The use of self-correction and peer feedback activities were \\
& introduced to the students, who were in the self-correction group, \\
& paper-pencil peer feedback group, and online peer feedback \\
& group. The objectives, contents, and scoring rubric of the writing \\
& tasks were also discussed. The students were trained in how to \\
& provide effective feedback by using self-correction, paper-pencil \\
& or Facebook according to the experimental groups they belonged \\
& to. \\
& Throughout the course, the students in each group had to write \\
four writing assignments (2-3 weeks for each assignment). & \\
II & The three experimental groups provided feedback on the writing \\
tasks. & The three groups took the post-test and questionnaire. Further, 9 \\
III & $\begin{array}{l}\text { students from each group were randomly assigned to the } \\
\text { interview session. }\end{array}$
\end{tabular}

\subsection{Data Analysis}

To answer the first three research questions, two-way ANOVA (F test) was used to analyze the main effects and the interaction effect of different types of feedback and levels of students' general English proficiency. Since the main effects of the two independent variables were found, Scheffe's Test was performed to further examine the differences elicited in research questions 1 and 2.

For the forth research objective, surveying the students' attitudes toward the type of feedback they had experienced in terms of efficiency, affective and cognitive aspects, and Thai cultural dimensions. The mean score of the total sample responses for each item and its Standard Deviation (S.D.) was calculated. Additionally, the data from the open-ended questionnaire and interview were analyzed and categorized under positive responses or negative responses.

\section{Results of the Study}

\subsection{A Comparison of the Main Effects of Types of Feedback on the Students' Writing} Achievement

In order to answer research questions 1-3, a two-way ANOVA was employed to investigate the main effects and the interaction effects of the types of feedback and levels of general English proficiency on the students' writing achievement. The findings are presented in the following table.

Table 2.

Tests of between-subject effects

\begin{tabular}{cccccc}
\hline Source & $\begin{array}{c}\text { Type III Sum } \\
\text { of Squares }\end{array}$ & df & $\begin{array}{c}\text { Mean } \\
\text { Square }\end{array}$ & F & $\begin{array}{c}\text { Partial Eta } \\
\text { Squared }\end{array}$ \\
\hline Types of feedback & 1158.61 .068 & 2 & 579.304 & $26.311^{*}$ & 0.455 \\
Levels of general & 5505.08 & 2 & 2752.54 & $125.017^{*}$ & 0.799
\end{tabular}




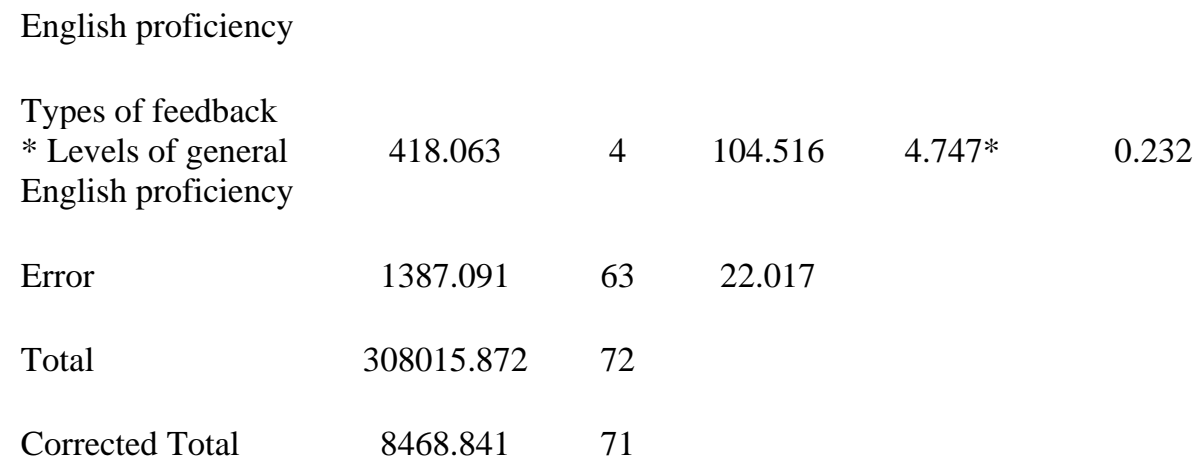

$$
* \mathrm{p}<.05
$$

To investigate the effects of types of feedback on the students' writing achievement, the results from the two-way ANOVA in Table 2 showed that the different types of feedback had a significant effect on the students' writing achievement $(\mathrm{F}=26.31, \mathrm{p}<.05)$. Hence, the first research hypothesis was accepted. In addition, it was found that the mean scores of the students in the online peer feedback group (mean $=67.96$ were higher than those of the paper-pencil peer feedback group (mean $=64.33$ ), and the self-correction group (mean $=53.88$ ). Since the differences of the students' writing achievement from types of peer feedback were found, Scheffe's test, a post-hoc comparison test for equal variance assume, was performed.

Table 3.

Results of a post-hoc multiple comparison test of the three types of feedback

\begin{tabular}{lllll}
\hline \multicolumn{1}{c}{ Comparison } & & Mean Difference & Std. Error & Sig. \\
\hline Self-correction Group & Paper-pencil Peer Feedback & $-7.7904^{*}$ & 1.35454 & .000 \\
& Online Peer Feedback & $-9.0812^{*}$ & 1.35454 & .000 \\
Paper-pencil Peer Feedback & Self-correction Group & $7.7904^{*}$ & 1.35454 & .000 \\
& Online Peer Feedback & -1.2908 & 1.35454 & .637 \\
Online Peer Feedback & Self-correction Group & $9.0812^{*}$ & 1.35454 & .000 \\
& Paper-pencil Peer Feedback & $1.2908^{*}$ & 1.35454 & .637 \\
\hline
\end{tabular}

$* \mathrm{p}<.05$

Table 3 presents that the students in the self-correction group performed differently from those in the paper-pencil peer feedback group and online peer feedback group. However, the mean difference was not found between the paper-pencil peer feedback group and the online peer feedback.

\subsection{A Comparison of the Main Effects of Levels of General English Proficiency on the Students' Writing Achievement}

According to the second research objective, which was to investigate the effects of the levels of general English proficiency on the students' writing achievement, the results from the twoway ANOVA illustrated that the levels of general English proficiency had a significant effect on the students' writing achievement score $(\mathrm{F}=125.02, \mathrm{p}<.05)$. Therefore, the second research hypothesis was accepted. The mean score of the writing test revealed that the high proficiency group outperformed the moderate proficiency group, and the moderate group outperformed the low proficiency group.

Since there were three ability groups in the study, a post-hoc comparison was used to identify where the differences occurred. Results of the Scheffe's test are presented in Table 4. It was found that the subjects in different general English proficiency levels all performed differently. The high proficiency group performed differently from the moderate and the low proficiency one. Similarly, the moderate proficiency group performed differently from the low proficiency group. Considering the mean scores, it could be concluded that the high proficiency group 
performed better than the moderate proficiency group and the moderate group performed better than the low proficiency group.

Table 4.

Results of a post-hoc multiple comparison test of the three levels of English proficiency

\begin{tabular}{lllll}
\hline \multicolumn{1}{c}{ Comparison } & & $\begin{array}{c}\text { Mean } \\
\text { Difference }\end{array}$ & $\begin{array}{c}\text { Std. } \\
\text { Error }\end{array}$ & Sig. \\
\hline Low proficiency group & Moderate proficiency group & $-10.46^{*}$ & 1.35 & .000 \\
& High proficiency group & $-21.42^{*}$ & 1.35 & .000 \\
Moderate proficiency group & Low proficiency group & $10.46^{*}$ & 1.35 & .000 \\
& High proficiency group & $-10.96^{*}$ & 1.35 & .000 \\
High proficiency group & Low proficiency group & $21.42^{*}$ & 1.35 & .000 \\
& Moderate proficiency group & $10.96^{*}$ & 1.35 & .000 \\
\hline
\end{tabular}

$* \mathrm{p}<.05$

\subsection{The Interaction Effect of Types of Peer Feedback and Levels of General English Proficiency on the Students' Writing Achievement}

According to Hatch and Farhady (1982), it is said that if an interaction is significant, it means that while one method of instruction did work better than the other; this may be due to the second factor. An interaction effect exists when differences on one factor depend on another factor.

In addition to the main effect, Table 4 illustrates the $\mathrm{F}$-ratio for the interaction of types of feedback and general English proficiency on writing achievement was 4.75. The p value was less than the 0.05 critical value.

Based on the results from the two-way ANOVA, it was shown that there was an interaction effect of the types of feedback and levels of general English proficiency on the students' writing achievement $(\mathrm{F}=4.75, \mathrm{p}>.05)$. Therefore, the third research hypothesis was rejected. There might be a tendency to find that levels of English proficiency yield a significant interaction effect on the types of feedback. In other words, the results showed that the low proficiency group learned best in the paper-pencil peer feedback. However, the score difference was not shown in the high proficiency group and the moderate proficiency group.

As a result, the third hypothesis, which states that there is no interaction effect between types of peer feedback and levels of general English proficiency on students' writing achievement at 0.05 level, was rejected. To put it more simply, there was an significant interaction effect of types of peer feedback and general English proficiency on writing achievement. Although the high proficiency students performed better than moderate proficiency students, and moderate proficiency students performed better than low proficiency ones regardless of the types of feedback they received, the result showed that the low proficiency students in the paper-pencil peer feedback group outperformed the low proficiency students in the other two experimental groups.

3.4 The Investigation of Students' Attitudes toward the use of feedback they experienced in terms of efficiency, affective aspect, cognitive aspect, and Thai cultural dimensions.

In order to answer the fourth research objective, investigating the students' attitudes toward the use of feedback they experienced in terms of efficiency, affective aspect, cognitive aspect, and Thai cultural dimensions, the questionnaire items were analyzed, as presented in Table 4. A five-point Likert scale, ranging from Strongly Disagree (1) to Strongly Agree (5), was used. To make the data more clear, the students' attitudes were interpreted by using the evaluation criteria described below:

0.00-1.50 means that the students had very low agreement with the statement.

1.51-2.50 means that the students had low agreement with the statement. 
2.51-3.50 means that the students had moderate agreement with the statement.

3.51-4.50 means that the students had strong agreement with the statement.

4.51-5.00 means that the students had very strong agreement with the statement.

Table 5.

Students' attitudes toward the use of feedback they experienced in terms of efficiency

\begin{tabular}{|c|c|c|c|c|c|c|}
\hline \multirow{2}{*}{ Statement } & \multicolumn{2}{|c|}{$\begin{array}{l}\text { Self-correction } \\
\text { group }\end{array}$} & \multicolumn{2}{|c|}{$\begin{array}{c}\text { Paper-pencil peer } \\
\text { feedback group }\end{array}$} & \multicolumn{2}{|c|}{$\begin{array}{c}\text { Online peer } \\
\text { feedback group }\end{array}$} \\
\hline & Mean & S.D. & Mean & S.D. & Mean & S.D. \\
\hline \multicolumn{7}{|l|}{ Efficiency } \\
\hline $\begin{array}{l}\text { 1. I think the type of feedback that I experienced is a } \\
\text { useful activity. }\end{array}$ & $\begin{array}{l}3.29 \\
(\mathrm{M})\end{array}$ & 1.20 & $\begin{array}{l}3.75 \\
(\mathrm{H})\end{array}$ & 1.51 & $\begin{array}{l}3.92 \\
(\mathrm{H})\end{array}$ & 0.92 \\
\hline $\begin{array}{l}\text { 2. The process of feedback that I experienced is worth } \\
\text { doing. }\end{array}$ & $\begin{array}{l}3.5 \\
(\mathrm{H})\end{array}$ & 1.10 & $\begin{array}{l}3.54 \\
(\mathrm{H})\end{array}$ & 1.32 & $\begin{array}{l}3.75 \\
(\mathrm{H})\end{array}$ & 0.68 \\
\hline $\begin{array}{l}\text { 3. The type of feedback that I experienced in the writing } \\
\text { class is a time consuming activity. }\end{array}$ & $\begin{array}{l}3.21 \\
(\mathrm{M})\end{array}$ & 1.14 & $\begin{array}{l}3.42 \\
(\mathrm{M})\end{array}$ & 1.38 & $\begin{array}{l}3.33 \\
(\mathrm{M})\end{array}$ & 0.82 \\
\hline $\begin{array}{l}\text { 4. The type of feedback that I experienced in the writing } \\
\text { class is effective. }\end{array}$ & $\begin{array}{l}3.38 \\
(\mathrm{M})\end{array}$ & 1.74 & $\begin{array}{l}3.54 \\
(\mathrm{H})\end{array}$ & 0.88 & $\begin{array}{l}3.79 \\
(\mathrm{H})\end{array}$ & 1.14 \\
\hline $\begin{array}{l}\text { 5. The type of feedback that I experienced in the writing } \\
\text { class costs a lot of money (such as internet bill) }\end{array}$ & $\begin{array}{l}2.88 \\
(\mathrm{M})\end{array}$ & 0.85 & $\begin{array}{l}3.04 \\
(\mathrm{M})\end{array}$ & 1.46 & $\begin{array}{l}3.21 \\
(\mathrm{M})\end{array}$ & 1.25 \\
\hline
\end{tabular}

*VH= very high, $\mathrm{H}=$ high, $\mathrm{M}=$ moderate, $\mathrm{L}=$ low, and $\mathrm{VL}=$ very low

The results illustrated that the students in the paper-pencil peer feedback and the online peer feedback groups seemed to moderately with the negative statements toward the efficiency of feedback type they experienced while the students strongly agreed with the usefulness and effectiveness of the online peer feedback.

Table 6.

Students' attitudes toward the use of feedback they experienced in terms of affective aspect

\begin{tabular}{|c|c|c|c|c|c|c|}
\hline \multirow[t]{2}{*}{ Statement } & \multicolumn{2}{|c|}{$\begin{array}{l}\text { Self-correction } \\
\text { group }\end{array}$} & \multicolumn{2}{|c|}{$\begin{array}{l}\text { Paper-pencil peer } \\
\text { feedback group }\end{array}$} & \multicolumn{2}{|c|}{$\begin{array}{c}\text { Online peer } \\
\text { feedback group }\end{array}$} \\
\hline & Mean & S.D. & Mean & S.D. & Mean & S.D. \\
\hline \multicolumn{7}{|l|}{ Affective Aspect } \\
\hline $\begin{array}{l}\text { 1. I feel comfortable with the type of feedback that I } \\
\text { experienced. }\end{array}$ & $\begin{array}{l}2.83 \\
(\mathrm{M})\end{array}$ & 1.31 & $\begin{array}{l}3.42 \\
(\mathrm{M})\end{array}$ & 1.25 & $\begin{array}{l}3.71 \\
(\mathrm{H})\end{array}$ & 1.30 \\
\hline $\begin{array}{l}\text { 2. I am not frightened when using the type of feedback } \\
\text { that I experienced in the writing process. }\end{array}$ & $\begin{array}{l}3.88 \\
(\mathrm{H})\end{array}$ & 1.30 & $\begin{array}{l}3.21 \\
(\mathrm{M})\end{array}$ & 1.25 & $\begin{array}{l}3.50 \\
(\mathrm{M})\end{array}$ & 1.29 \\
\hline 3. I like the type of feedback that I experienced. & $\begin{array}{l}2.49 \\
(\mathrm{M})\end{array}$ & 0.89 & $\begin{array}{l}3.54 \\
(\mathrm{H})\end{array}$ & 0.93 & $\begin{array}{l}4.04 \\
(\mathrm{H})\end{array}$ & 0.71 \\
\hline 4. I feel anxious to this type of feedback. & $\begin{array}{l}4.11 \\
(\mathrm{H})\end{array}$ & 0.68 & $\begin{array}{l}3.50 \\
(\mathrm{M})\end{array}$ & 1.22 & $\begin{array}{l}3.46 \\
(\mathrm{M})\end{array}$ & 1.28 \\
\hline $\begin{array}{l}\text { 5. I feel that the writing class is more interesting when } \\
\text { applying this type of feedback. }\end{array}$ & $\begin{array}{l}3.04 \\
(\mathrm{M})\end{array}$ & 1.46 & $\begin{array}{l}3.89 \\
(\mathrm{H})\end{array}$ & 0.54 & $\begin{array}{l}4.09 \\
(\mathrm{H})\end{array}$ & 0.95 \\
\hline $\begin{array}{l}\text { 6. After taking this course, my feeling towards English } \\
\text { writing has changed positively. }\end{array}$ & $\begin{array}{l}3.50 \\
(\mathrm{M})\end{array}$ & 0.93 & $\begin{array}{l}3.63 \\
(\mathrm{H})\end{array}$ & 0.77 & $\begin{array}{l}3.79 \\
(\mathrm{H})\end{array}$ & 1.35 \\
\hline $\begin{array}{l}\text { 7. I feel more confident in writing because I have the } \\
\text { ability to give feedback. }\end{array}$ & $\begin{array}{l}3.21 \\
(\mathrm{M})\end{array}$ & 0.83 & $\begin{array}{l}4.00 \\
(\mathrm{H})\end{array}$ & 0.83 & $\begin{array}{l}4.20 \\
(\mathrm{H})\end{array}$ & 0.73 \\
\hline $\begin{array}{l}\text { 8. I feel that teacher feedback is better that the type of } \\
\text { feedback I experienced. }\end{array}$ & $\begin{array}{l}4.29 \\
(\mathrm{H})\end{array}$ & 1.00 & $\begin{array}{l}3.27 \\
(\mathrm{M})\end{array}$ & 1.01 & $\begin{array}{l}3.07 \\
(\mathrm{M})\end{array}$ & 0.89 \\
\hline $\begin{array}{l}\text { 9. I have fun while this type of feedback is implemented } \\
\text { in the writing class. }\end{array}$ & $\begin{array}{l}3.13 \\
(\mathrm{M})\end{array}$ & 1.45 & $\begin{array}{l}3.82 \\
(\mathrm{H})\end{array}$ & 0.91 & $\begin{array}{l}4.08 \\
(\mathrm{H})\end{array}$ & 0.78 \\
\hline $\begin{array}{l}\text { 10. I feel relaxed to use this type of feedback in the } \\
\text { writing process. }\end{array}$ & $\begin{array}{l}3.07 \\
(\mathrm{M})\end{array}$ & 0.89 & $\begin{array}{l}3.50 \\
(\mathrm{M})\end{array}$ & 1.47 & $\begin{array}{l}3.33 \\
(\mathrm{M})\end{array}$ & 0.96 \\
\hline
\end{tabular}


In terms of affective aspect, the results illustrated that the students in the paper-pencil peer feedback and the online peer feedback groups seemed to have highly positive feelings towards the peer feedback activity while the students in the self-correction group feel more anxious (item 4, M=4.11, S.D.=0.68), less relaxed (item 10, M=3.07, S.D.=0.89), and more dependent on teacher feedback (item 8, M=4.29, S.D.=1).

Regarding the cognitive aspects (Table 7), the results illustrated that the students in the paperpencil and online peer feedback groups seemed to strongly agree with the positive statements toward the efficiency of the peer feedback activity, but the self-correction group responses belong to moderately agree on all the positive statements.

Table 7.

Students' attitudes toward the use of feedback they experienced in terms of cognitive aspect

\begin{tabular}{|c|c|c|c|c|c|c|}
\hline \multirow[t]{2}{*}{ Statement } & \multicolumn{2}{|c|}{$\begin{array}{l}\text { Self-correction } \\
\text { group }\end{array}$} & \multicolumn{2}{|c|}{$\begin{array}{c}\text { Paper-pencil peer } \\
\text { feedback group }\end{array}$} & \multicolumn{2}{|c|}{$\begin{array}{c}\text { Online peer } \\
\text { feedback group }\end{array}$} \\
\hline & Mean & S.D. & Mean & S.D. & Mean & S.D. \\
\hline \multicolumn{7}{|l|}{ Cognitive Aspect } \\
\hline 1. I believe that this type of feedback is helpful. & $\begin{array}{l}3.29 \\
(\mathrm{M})\end{array}$ & 1.08 & $\begin{array}{c}4.00 \\
(\mathrm{H})\end{array}$ & 0.59 & $\begin{array}{c}4.29 \\
(\mathrm{H})\end{array}$ & 1.00 \\
\hline $\begin{array}{l}\text { 2. I think the type of feedback that is useful when } \\
\text { applied in the writing course. }\end{array}$ & $\begin{array}{l}3.04 \\
(\mathrm{M})\end{array}$ & 0.95 & $\begin{array}{l}3.67 \\
(\mathrm{H})\end{array}$ & 0.96 & $\begin{array}{c}4.08 \\
(\mathrm{H})\end{array}$ & 0.78 \\
\hline $\begin{array}{l}\text { 3. The type of feedback helps me recognize errors } \\
\text { better. }\end{array}$ & $\begin{array}{l}3.17 \\
(\mathrm{M})\end{array}$ & 1.09 & $\begin{array}{l}3.42 \\
(\mathrm{M})\end{array}$ & 1.38 & $\begin{array}{l}3.67 \\
(\mathrm{H})\end{array}$ & 0.96 \\
\hline $\begin{array}{l}\text { 4. Using the type of feedback encourages me to } \\
\text { acquire English writing knowledge. }\end{array}$ & $\begin{array}{l}3.25 \\
(\mathrm{M})\end{array}$ & 1.03 & $\begin{array}{c}3.63 \\
(\mathrm{H})\end{array}$ & 0.77 & $\begin{array}{l}3.71 \\
(\mathrm{H})\end{array}$ & 1.30 \\
\hline 5. The type of helps my writing well organized. & $\begin{array}{l}3.33 \\
(\mathrm{M})\end{array}$ & 1.09 & $\begin{array}{l}3.88 \\
(\mathrm{H})\end{array}$ & 0.83 & $\begin{array}{l}3.96 \\
(\mathrm{H})\end{array}$ & 0.86 \\
\hline $\begin{array}{l}\text { 6. My writing improved after using the type of } \\
\text { feedback that I experienced. }\end{array}$ & $\begin{array}{l}3.46 \\
(\mathrm{M})\end{array}$ & 1.14 & $\begin{array}{c}4.00 \\
(\mathrm{H})\end{array}$ & 0.66 & $\begin{array}{c}4.13 \\
(\mathrm{H})\end{array}$ & 0.68 \\
\hline $\begin{array}{l}\text { 7. I think the type of feedback helps me to become } \\
\text { an independent learner. }\end{array}$ & $\begin{array}{l}3.38 \\
(\mathrm{M})\end{array}$ & 1.17 & $\begin{array}{l}3.96 \\
(\mathrm{H})\end{array}$ & 0.55 & $\begin{array}{c}4.17 \\
(\mathrm{H})\end{array}$ & 0.64 \\
\hline $\begin{array}{l}\text { 8. The type of feedback that I experienced helps } \\
\text { improve the content of my writing. }\end{array}$ & $\begin{array}{l}3.13 \\
(\mathrm{M})\end{array}$ & 1.12 & $\begin{array}{l}3.56 \\
(\mathrm{H})\end{array}$ & 1.16 & $\begin{array}{c}4.08 \\
(\mathrm{H})\end{array}$ & 0.65 \\
\hline $\begin{array}{l}\text { 9. I have stronger critical awareness in writing than } \\
\text { before experiencing this feedback activity. }\end{array}$ & $\begin{array}{l}3.33 \\
(\mathrm{M})\end{array}$ & 1.09 & $\begin{array}{l}3.58 \\
(\mathrm{H})\end{array}$ & 1.14 & $\begin{array}{c}3.83 \\
(\mathrm{H})\end{array}$ & 1.17 \\
\hline $\begin{array}{l}\text { 10. I can evaluate the strengths and weakness of my } \\
\text { own work. }\end{array}$ & $\begin{array}{l}3.27 \\
(\mathrm{M})\end{array}$ & 1.01 & $\begin{array}{c}3.75 \\
(\mathrm{H})\end{array}$ & 0.68 & $\begin{array}{c}3.89 \\
(\mathrm{H})\end{array}$ & 0.80 \\
\hline
\end{tabular}

Table 8.

Students' attitudes toward the use of the type of peer feedback they experienced in terms of Thai cultural dimensions

\begin{tabular}{|c|c|c|c|c|}
\hline \multirow{2}{*}{ Statement } & \multicolumn{2}{|c|}{$\begin{array}{l}\text { Paper-pencil peer } \\
\text { feedback group }\end{array}$} & \multicolumn{2}{|c|}{$\begin{array}{c}\text { Online peer } \\
\text { feedback group }\end{array}$} \\
\hline & Mean & S.D. & Mean & S.D. \\
\hline \multicolumn{5}{|l|}{ Thai Cultural Dimensions } \\
\hline 1. I think teacher feedback is more reliable than peer feedback. & $\begin{array}{l}3.21 \\
(\mathrm{M})\end{array}$ & 1.32 & $\begin{array}{l}3.17 \\
(\mathrm{M})\end{array}$ & 1.13 \\
\hline 2. I feel comfortable to give feedback on my friend's work. & $\begin{array}{l}3.46 \\
(\mathrm{M})\end{array}$ & 1.38 & $\begin{array}{l}3.58 \\
(\mathrm{H})\end{array}$ & 1.25 \\
\hline 3. I think I can give honest feedback to my friend's work. & $\begin{array}{l}3.46 \\
(\mathrm{M})\end{array}$ & 0.78 & $\begin{array}{l}3.50 \\
(\mathrm{M})\end{array}$ & 1.25 \\
\hline 4. I feel embarrassed when my friends read my work. & $\begin{array}{c}3.54 \\
(\mathrm{H})\end{array}$ & 1.10 & $\begin{array}{c}3.54 \\
(\mathrm{H})\end{array}$ & 1.50 \\
\hline 5. I like giving peer feedback. & $\begin{array}{l}4.08 \\
(\mathrm{H})\end{array}$ & 0.50 & $\begin{array}{l}4.29 \\
(\mathrm{H})\end{array}$ & 1.00 \\
\hline $\begin{array}{l}\text { 6. I think my friends are not proficient enough to give me useful } \\
\text { feedback. }\end{array}$ & $\begin{array}{l}2.92 \\
(\mathrm{M})\end{array}$ & 0.41 & $\begin{array}{l}2.88 \\
(\mathrm{M})\end{array}$ & 0.85 \\
\hline
\end{tabular}




\begin{tabular}{|c|c|c|c|c|}
\hline $\begin{array}{l}\text { 7. I am concerned to my friends' feeling, so I try to avoid harsh } \\
\text { words while giving feedback. }\end{array}$ & $\begin{array}{c}4.20 \\
(\mathrm{H})\end{array}$ & 0.73 & $\begin{array}{r}4.29 \\
(\mathrm{H})\end{array}$ & 1.00 \\
\hline 8. My work is improved after implementing peer feedback. & $\begin{array}{r}4.00 \\
(\mathrm{H})\end{array}$ & 0.67 & $\begin{array}{c}4.08 \\
(\mathrm{H})\end{array}$ & 0.88 \\
\hline 9. I never implement peer feedback in my work. & $\begin{array}{c}1.51 \\
(\mathrm{~L})\end{array}$ & 0.73 & $\begin{array}{l}1.47 \\
(\mathrm{VL})\end{array}$ & 0.84 \\
\hline 10.I prefer peer feedback than teacher feedback. & $\begin{array}{c}4.07 \\
(\mathrm{H})\end{array}$ & 0.78 & $\begin{array}{c}4.21 \\
(\mathrm{H})\end{array}$ & 0.51 \\
\hline $\begin{array}{l}\text { 11. I am afraid that my friend will be angry if I give honest } \\
\text { feedback. }\end{array}$ & $\begin{array}{c}3.91 \\
(\mathrm{H})\end{array}$ & 0.82 & $\begin{array}{c}3.96 \\
(\mathrm{H})\end{array}$ & 0.86 \\
\hline 12. I feel unhappy when receiving direct peer feedback. & $\begin{array}{l}3.67 \\
(\mathrm{H})\end{array}$ & 0.96 & $\begin{array}{c}3.82 \\
(\mathrm{H})\end{array}$ & 0.91 \\
\hline 13. I think peer feedback is not necessary. & $\begin{array}{c}2.27 \\
(\mathrm{~L})\end{array}$ & 0.54 & $\begin{array}{c}2.08 \\
(\mathrm{~L})\end{array}$ & 1.06 \\
\hline $\begin{array}{l}\text { 14. I think I cannot give feedback because I am an inexperienced } \\
\text { writer. }\end{array}$ & $\begin{array}{l}2.91 \\
(\mathrm{M})\end{array}$ & 1.16 & $\begin{array}{l}2.96 \\
(\mathrm{M})\end{array}$ & 0.21 \\
\hline 15. I am confident that I can give helpful feedback. & $\begin{array}{r}3.67 \\
(\mathrm{H}) \\
\end{array}$ & 0.92 & $\begin{array}{c}3.88 \\
(\mathrm{H}) \\
\end{array}$ & 0.68 \\
\hline
\end{tabular}

As the cultural influence on the use of peer feedback activity, the 15-questionnaire items shown in Table 8 were required to answer by the two experimental groups, paper-pencil peer feedback and online peer feedback. Both groups moderately agreed with items 1,3, 6 and 14, while items 9 and 13 obtained the lowest mean scores.

\section{Discussion}

According to the first research objective, which was to investigate the effects of types of feedback on the students' writing achievement, the results from the two-way ANOVA showed that the different types of feedback had a significant effect on the students' writing achievement $(\mathrm{F}=26.31, \mathrm{p}<.05)$. Therefore, the first research hypothesis was accepted. Moreover, the mean scores of the students in the online peer feedback group (mean $=67.96)$ were higher than those of the paper-pencil peer feedback group (mean $=64.33$ ), and the self-correction group (mean =53.88). This may be due to the convenience of the social networking site, which facilitates the writing process and so may affect the quality of the students' writing. The students can learn from each other's writing assignments and feedback as they can read, model, comment on, and review at their own pace. This channel also motivated the students to write, as their work was published for an authentic audience. Furthermore, the results from the interview revealed that the students were more confident in their friends' comments when several friends made the same points. However, some confusion for the students in deciding what and how to edit and revise their writing occurred due to the multiple-voiced feedback.

In Thailand, the students are familiar with traditional assessment and rote learning from their previous learning experience. They are not allowed to speak out their own thoughts, give comments on their classmates' writing, assess their friends' work, or evaluate their own learning. All the aforementioned tasks are believed to be the teachers' responsibility, especially in the EFL contexts since the higher-context cultures in which authority is primarily in the teachers' hands have a major role to play, so it seems inappropriate for students to question their teachers as it is believed that the students are not in a position to share or express ideas (Baker, 2013).

The process-based approach underpinned this course, and multiple drafts writing focusing on revision based on various sources of was the main focus, so a single-timed writing test seemed to be an inappropriate and ineffective method for tracking the students' writing ability and development. A positive washback effect exists when the instructional method is consistent with the course assessment. Therefore, the sense of purpose of learning and doing the assigned 
tasks was promoted. The students knew what, why, and how they learned through this peer feedback activities.

According to the second research objective concerning to the levels of general English proficiency, the results showed that the students' writing achievement scores of the high-, moderate-, and low-proficiency groups were significantly different. Previous studies have pointed that there is a strong positive relationship between writing ability and general English proficiency. Moreover, the different writing process behaviors of the three proficiency groups were another significant reason to explain the significantly different writing scores of the three proficiency groups. As pointed out by Richards (1990), skilled writers spend more time at the pre-writing stage, use various writing and revising strategies, and have sufficient language resources to enable them to concentrate on meaning more than grammatical aspects, for example. High-proficiency learners tend to use learning strategies more effectively, so they are more successful in language learning. Further, the motivation, effort, and levels of self-directed ability of the high proficiency students are normally higher than low-proficiency groups. An interesting finding was that all three groups of students gained better scores compared to the pretest. It could be said that the designated activities helped them to learn as their writing ability was seen to improve.

The results illustrated that the students seemed to have highly positive attitudes toward the type of feedback they experienced, as they highly agreed with most of the positive items. However, it is noteworthy to mention that the self-correction group had the lowest mean scores of all the items compared to the other two groups. The results of the interview asking the students indepth information about their attitudes and feelings toward the type of feedback they experienced in the class revealed that the students from the self-correction group thought that the self-correction strategy was very helpful, as it encouraged them to be aware of the elements of good paragraph writing, but it was sometimes difficult for them to make corrections themselves without teacher or peer intervention due to their limited language knowledge.

The results revealed that online peer feedback was the type of response that the students preferred most due to the beneficial functions of the social networking site from various perspectives. With respect to the cognitive perspective, in terms of writing development, the majority of the students reported that the integration of Facebook and peer feedback helped them improve their writing in all focused writing aspects, such as content, organization, vocabulary, and mechanics. In terms of the social perspective, it can be said that Facebook can serve the students' lifestyles, as it has become an important part of their everyday life for communication among friends. The usefulness of the functions and applications on Facebook not only provides a supportive environment for collaborative and cooperative learning, but also provides a platform to learn writing through social interactions. The interview results showed that the students felt excited and motivated when they posted their work and waited for comments. Also, their interaction increased. Although the Thai language could be used as a mean for communication, the students tried to communicate in English for asynchronous and synchronous interactions. However, off-task comments were also found.

Based on the students' perceptions, the students seemed to have positive feelings toward the use of social networks, an idea that conforms with many studies. However, in the EFL writing class, the negative aspects that devalued the benefits of the social network are the feeling of shyness when the students received comments from their peers or when the errors in their writing were revealed as they considered that they lost their face in public. This social embarrassment is considered to be one of the important threats to one's social identity, which may cause learning anxiety (Tanveer, 2008) and may affect subsequent learning achievement and proficiency more than instrumental and integrative motivation (Paige, Jorstad, Siaya, Klein, \& Colby, 2000 cited in Young, 2012). 
The study's findings are consistent with previous research (Maneeratphairoj and Wanchid, 2015; Thongrin, 2002; Wanchid, 2008), which pointed out that some Thai cultural traits such as the notion of face, ego-orientation, maintaining group harmony, and Kreng Jai (the concern for other people's feelings) are significant barriers that downgrade the value of peer feedback. To lessen this cultural impact, an anonymous peer feedback environment is recommended in order to gain honest feedback from the peer group, and the objectives of the peer feedback activity and the role of the feedback provider should be clear enough to students so that they can build a sense of trust in a cooperative learning environment. As suggested by Young (2012, p. 24), "certain cultural shifts will be necessary if Thailand is to reach its desired goal of nationwide proficiency in English." To achieve this mission, the responsibility is bestowed on the teachers to push this expected goal to reality.

Self-correction seemed to be the strategy that received moderately positive responses from low and moderate proficiency students. Unlike the high-proficiency students, the low and moderate students said that it was difficult for them to correct their own work because of their limited linguistic knowledge. They were not ready for self-directed learning, and their learning styles seemed to prefer group work instead of individual work. Further, previous research has shown that the students seemed to have negative attitudes and motivation toward learning English, and their writing behaviors are different than skilled writers, as they spend less time on prewriting tasks. A number of students reported that self-correction was the most stressful feedback strategy because they could not find the errors or mistakes by themselves. As a result, employing this in the first strategy among the three types may increase their anxiety and apprehensiveness. Therefore, teachers should consider both internal and external learner variables in order to maximize the students' learning outcomes or the sequence of the activities before implementing them in the course.

\subsection{Pedagogical Implications}

The use of alternative assessment in the EFL writing class yields undeniable benefits, as it encourages students to develop a sense of independent learning in various degrees of success. This opportunity also creates students' critical thinking and self-reliance, which would be rare in a traditional teacher-centered writing class. However, failure to use the alternative assessment can possibly occurs without clear learning objectives, well-planned lessons, teachers' determination and efforts, effective feedback training, and the learners' full cooperation. Writing teachers in the EFL context should consider the constraints of their teaching and learning contexts, such as levels of English proficiency, cultural context, and Internet accessibility before exploiting these activities in their writing classes. More importantly, teachers should be aware of what, when, and how teacher feedback should be used.

\section{Acknowledgement}

I would like to show my deepest gratitude to the Faculty of Applied Arts, King Mongkut's University of Technology North Bangkok for the research grant. Special thanks go to all of my students who were participating in this research. Without their effort, hard work, enthusiasm, and cooperation, this research would have never been successfully conducted.

\section{References}

Ancker, W. (2000). Errors and corrective feedback: Updated theory and classroom practice. English Teaching Forum, Vol. 38, No.4, pp 20-24.

Baker, W. (2013). A critical examination of ELT in Thailand: The role of cultural awareness. RECL, Vol. 39, No.1, pp. 131-146. 
Hatch, E., \& Farhady, H. (1982). Research design and statistics. Tehran: Rahnama Publications.

Hyland, K. (2003). Second language writing. Cambridge: Cambridge University Press.

Liu, J., and Hansen, J. (2002). Peer response in second language writing classrooms. Ann Arbor: University of Michigan Press.

Maneeratphairoj, K., \& Wanchid, R. (2015). The Effects of Peer Feedback and Self Correction on Writing Ability: A Case of Social Network Medium (Unpublished master's thesis). King Mongkut's University of Technology North Bangkok, Bangkok.

Richards, J. (1990). From meaning into words: Writing in a second or foreign language. In J. Richards, The language teaching matrix. Cambridge, England and New York: Cambridge University Press. 100-117.

Tanveer, M. (2008). Investigation of the factors that cause language anxiety for ESL/EFL learners in learning speaking skills and the influence it casts on communications in the target language. Asian EFL Journal. Retrieved April 17, 2014 at http: // www.asian-efljournal/thesis_M_Tanveer.pdf

Thongrin, S. (2002). E-mail peer responses in collectivist Thai culture: Task, social and cultural dimensions. Doctoral dissertation. The Graduate School and Research Department of English, Indiana University of Pennsylvania.

Wanchid, R. (2008). The effects of types of peer feedback and levels of general English proficiency on writing achievement of KMITNB students: Unpublished Ph.D. Dissertation, Chulalongkorn University.

Yang, Y. (2010). Students' reflection on online self-correction and peer review to improve writing. Computer and Education, Vol. 55, pp. 1202-1210.

Young, D. (2012). Road to nowhere: The effects of culture on Thai learners of English. Poster presented at the International Seminar: Researching English in the Workplace: Meeting the Needs of the ASEAN Economic Community (AEC), Chulalongkorn University, Bangkok. 